University of Massachusetts Amherst ScholarWorks@UMass Amherst

Published Work

Center for Student Success Research

2017

\title{
Financial Planning for College: Parental Preparation and Capital Conversion
}

Catherine A. Manly

University of Massachusetts Amherst

Ryan S. Wells

University of Massachusetts Amherst

Genia Bettencourt

University of Massachusetts Amherst

Follow this and additional works at: https://scholarworks.umass.edu/cfssr_publishedwork

Part of the Higher Education Commons

\section{Recommended Citation}

Manly, Catherine A.; Wells, Ryan S.; and Bettencourt, Genia, "Financial Planning for College: Parental Preparation and Capital Conversion" (2017). Journal of Family and Economic Issues. 6.

https://doi.org/10.1007/s10834-016-9517-0

This Article is brought to you for free and open access by the Center for Student Success Research at ScholarWorks@UMass Amherst. It has been accepted for inclusion in Published Work by an authorized administrator of ScholarWorks@UMass Amherst. For more information, please contact scholarworks@library.umass.edu. 
Running head: PARENTAL COLLEGE FINANCIAL PLANNING

Financial Planning for College: Parental Preparation and Capital Conversion

\author{
Catherine A. Manly \\ Ryan S. Wells ${ }^{\mathrm{b}}$ \\ Genia M. Bettencourt ${ }^{\mathrm{a}}$
}

Author Affiliations and Addresses:

${ }^{a}$ N119 Furcolo Hall; Department of Educational Policy, Research and Administration;

University of Massachusetts Amherst; Amherst, MA 01003

${ }^{b}$ N172 Furcolo Hall; Department of Educational Policy, Research and Administration;

University of Massachusetts Amherst; Amherst, MA 01003

\begin{abstract}
:
This study explores the conversion of cultural capital into economic capital, and specifically financial capital in the form of parental financial planning for children's college education, including reported financial preparations and savings. Using data from the Education Longitudinal Study (ELS:2002), logistic regression-based analyses of aspects of cultural capital indicated that parental involvement exhibited the most prevalent relationship with financial planning and the amount saved, and that parents' expectations, but not their aspirations, corresponded to engagement in financial planning. Findings support the conclusion that some parents convert part of their cultural capital to financial capital in preparation for paying for their child's college education, perhaps representing a typically hidden facet of social class reproduction.
\end{abstract}

Keywords: parental financial planning; college saving; cultural capital; financial capital; capital conversion

Acknowledgements: The authors wish to thank Robert Gable, Gary Malaney, Greg Wolniak, and Jessica Wolpaw for helpful comments on early drafts of this paper, although of course, any errors or omissions in the final paper are solely the responsibility of the authors.

For information about this paper, please contact:

Catherine Manly

N119 Furcolo Hall

University of Massachusetts Amherst

Amherst, MA 01003

cmanly@educ.umass.edu

phone: 413-545-0871

fax: 413-545-1523 


\section{Financial Planning for College: Parental Preparation and Capital Conversion}

As parents in the United States (US) prepare to make contributions toward a child's college expenses, the unknown but potentially large investment draws upon multiple types of familial resources. In 2015, for the first time since 2010, parent contributions provided students' largest source of college funding in the US, surpassing scholarships and grants (Sallie Mae 2015a). Despite the importance that society and most parents have placed on college education (Napolitano et al. 2014; Sallie Mae 2015a), there has been relatively little research on the financial actions that could facilitate turning expectations into postsecondary attendance and persistence (Horn et al. 2003).

Previous studies have examined how different forms of parental capital connect to college expectations, institutional choice, and enrollment (Engberg and Allen 2011; Kim and Sherraden 2011; Song and Elliott 2012). For example, students from backgrounds where parents saved more and had more assets attended four-year colleges at higher rates, reinforcing existing privilege for these children. Other research has explored parental anticipation of providing financial assistance (Herrold and O'Donnell 2008; Immerwahr 2000; Lippman et al. 2008), as well as parental allocation choices to shelter college savings (Reyes 2008). However, beyond Sallie Mae's (2015b) annual report examining how parents save for college via various mechanisms, there has been a general lack of scholarship concerning what parents choose to do financially during their children's growing years, and what factors may be related to these decisions. The sensitive nature of personal finances, a general unwillingness among people to divulge personal financial information, and a paucity of relevant data containing information on parental financial planning during the pre-college years have proven to be substantial barriers to research.

Faced with a wide array of college savings options, most families ultimately have combined several approaches. Many options have been folded into the fabric of general family savings, while other strategies involve adjusting expenses or working more. Remortgaging property has offered additional access to cash flow. Children have also been expected to set aside some of their earnings from jobs during high school. Parents who have planned ahead may use a variety of tax-advantaged savings plans. ${ }^{1}$ These vehicles have intended to make postsecondary education more affordable given federal budget policy emphasizing use of the tax system over discretionary spending (Jennings and Olivas 2000), but have been primarily used by relatively wealthier families (Dynarski 2004).

\footnotetext{
${ }^{1}$ Such plans include Coverdell Education Savings Accounts (ESAs, previously called Education IRAs) and Qualified Tuition Programs (QTPs) authorized by Section 529 of the Internal Revenue Code. With these 529 plans, the US federal government allows individual states to create tax-advantaged programs to encourage parents to save money toward their child's college education. These programs can either be general college savings plans intended for use wherever the child goes or prepaid tuition plans tied to specific institutions.
} 
Choosing an optimal approach can be confusing for families, particularly those from lower socioeconomic circumstances who may have lacked higher education exposure, and who may have used and comprehended the information available to them differently than families of greater means (Luna de la Rosa 2006; Perna 2006; Trent et al. 2006). Such disadvantaged families may be at risk of choosing strategies that do not match their socioeconomic circumstances well. For example, they may not be aware of financial aid rules tapping savings in a child's name at higher rates than parental savings. The potential for such choices to exacerbate inequities faced by children from lower class families in the processes of applying, getting accepted, and paying for college has reinforced the importance of understanding the role of parental financial planning more fully. In short, social class differences are likely to influence not only how much money may be saved by families, but the specific behaviors and mechanisms of parental financial planning.

Bourdieu (1986) has used a multi-dimensional view of capital to illuminate the nuances of class differences, stressing that cultural factors play a significant role in addition to economic ones. Families may hold both economic capital and cultural capital in differing degrees. Cultural capital may influence the actions parents take when deciding if and/or how to plan financially for college. Obviously, wealthier parents have greater capacity to set aside money in preparation. However, the relative importance of income compared to embodied forms of cultural capital has not been clear. While we expect that class differences play a significant role in family preparation to pay for college, the relative importance of various manifestations of a family's capital need to be explored.

We focused our investigation on the effects that several components of cultural capital had on parental financial planning for their child's college education. If families were able to convert their cultural capital into economic capital, and specifically financial capital for college, as Bourdieu's work suggested, it makes sense that some parents would choose to do this. We investigated the evidence of such capital conversion in college financial planning using the 2002 Education Longitudinal Study's (ELS:2002) survey of parents of high school students, which asked about a range of financial actions taken to plan for college expenses (National Center for Education Statistics 2002). While doing so, we aimed in this study to identify factors associated with various types of postsecondary financial preparation among parents of $10^{\text {th }}$ graders. 


\section{Background}

\section{Capital Conversion Theoretical Framework}

College enrollment depends on a number of factors. One of the most frequently demonstrated predictors has been family income, wealth, or some other form of economic capital. The college transition literature has demonstrated that additional family related factors have been predictive of postsecondary matriculation, such as parental expectations, parental involvement, and resources in the home. Several higher education scholars have framed these variables as components of cultural and/or social capital (e.g., McDonough et al. 1997; Paulsen and St. John 2002; Perna 2000; Perna and Titus 2005; Walpole 2007; Wells 2008). ${ }^{2}$

Cultural capital (Bourdieu 1986; Bourdieu and Passeron 1977) has included forms of symbolic wealth that help define a person's class and that have often been inherited from one's family, therefore potentially helping to sustain upper- and middle-class status groups (McDonough 1997, 1998; Swartz 1997). Closely related has been one's habitus, defined as "a system of lasting, transposable dispositions" which generate actions (Bourdieu 1971, p. 83), and can be thought of as a manifestation of cultural capital (Berger 2000). Habitus is an unconscious, internalized force which predisposes those of given social classes, and with similar cultural capital, to take advantage of certain opportunities available to them. In our case, habitus involves actions in financial preparation for a child's college education. Given this framework, a family's involvement with, expectations of, and aspirations for their child would be fundamental components of the student's habitus and therefore forms of cultural capital.

Some factors mentioned above have also been defined as social capital by some scholars. While social capital has had several different conceptualizations (Bourdieu 1986; Coleman 1988, 1990; Lin 2001; Portes 1998; Putnam 2000), it typically has included the social and personal networks people utilize for interpersonal assistance, which for students often develop in the home as well as the school and other locations. In this way, parents' involvement with students may be interpreted as part of the student's network. However, interpersonal networks are not investigated here. Instead of evaluating the role of students' networks interpreted as social capital, we focus on embodied aspects of a child's family cultural capital and thus conceptualize parental involvement as one of these embodied aspects. ${ }^{3}$

\footnotetext{
2 There have been warnings against superficial quantitative operationalization of social and cultural capital (Smart 2005), which we acknowledge and seek to avoid.

${ }^{3}$ Although Martin and Spenner (2009) note: "Bourdieu considers the academic skills, values and abilities that we regard as dimensions of human capital as examples of embodied cultural capital" (p. 626), we chose to consider
} 
According to Bourdieu (1986), the forms of capital may be converted from one form to another. While Bourdieu has recognized that when conversion happens it is not complete due to the separate natures of the various forms of capital, he has claimed that conversion to economic capital could be effected given appropriate amounts of time. The concealed nature of this potentially slow conversion was one of the mechanisms by which he saw society's class structure reproduced over time; cultural capital has contributed to the hidden nature (or misrecognition) of that reproduction. In the current study, by looking at the families of $10^{\text {th }}$ graders, roughly fifteen years have been available to parents in which to use their cultural capital in ways that could convert it to economic capital, specifically in terms of financial planning actions and financial capital targeted for college. This ought to have allowed sufficient time for capital conversion to be apparent from the aspects of embodied cultural capital we investigate.

Drawing upon Bourdieu's work with Passeron, researchers Martin and Spenner (2009) used the theoretical framework of capital conversion to study legacy students in college. These authors noted that "processes that support academic achievement, such as cognitive development, habits and values, and financial investments in schooling are central in intergenerational transmission" (p. 625). We also examine intergenerational transmission via capital conversion prior to college, focusing on financial investments in schooling. While income is clearly a major factor for college financial planning, we are interested primarily in certain aspects of cultural capital that may be converted to financial capital, controlling for family income. In this way, we are not framing family aspirations, expectations, and involvement solely as direct influences on college enrollment, but also as indirect influences via conversion of those non-financial family assets into financial resources specifically designated for the student's continued education.

\section{Connections to College Financial Planning}

Aspects of cultural capital. Studies linking parental expectations with anticipation of providing financial assistance typically have not distinguished parents' idealistic aspirations from more realistic expectations for their children (Herrold and O'Donnell 2008; Lippman et al. 2008). Also, the various demographic and educational characteristics which relate to college financial planning have either not been connected to the distinction between parental expectations and aspirations or to the type(s) of planning behaviors which actually occurred (DeVaney and

parental and grandparental education as human capital, including them as controls (Becker 1993; Coleman 1988). This allows us to argue clearly for a conversion of capital without appealing to these variables, which economists might consider differently than sociologists. 
Chien 2002; Dynarski 2004; Horn et al. 2003; Yilmazer 2008). Therefore, the relationships between parental aspirations and expectations and specific types of college financial planning behaviors have not yet been fully investigated.

Similarly, while parental school involvement has been linked to education savings (Horn et al. 2003), it has not been connected with specific actions taken by parents to plan financially for college. Among the multiple proposed approaches to understanding parental involvement (Fan and Chen 2001; Grolnick et al. 1997; HooverDempsey and Sandler 1997), both home- and school-based aspects have been identified as relevant to an overall understanding of parental involvement in a child's schooling (Hoover-Dempsey and Sandler 1997). Previous analyses of parental financial planning, however, have not utilized this more inclusive view of parental involvement by including activities and cognitive involvement parents have with children outside of school (Grolnick et al. 1997).

Income. While neither income nor regularity of family saving has been shown to impact attitudes toward college savings (DeVaney et al. 2007; DeVaney and Chien 2002), research has shown that income has affected actual college financial planning behavior (Elliot and Friedline 2013; Horn et al. 2003). Other studies have shown that although approximately $50 \%$ of parents of pre-college students save for college (Sallie Mae 2015b), low-income parents have been not only less likely to have started saving or thought about paying for college, but have been more likely to report having no way of getting money for college for their children (Sallie Mae 2015b; Williams Shanks et al. 2014). Also, investors in state-sponsored college savings plans (e.g., 529 plans) typically have had relatively high income, net worth and retirement savings (Dynarski 2004; Sallie Mae 2015b). In other words, 529-savers have already been savers more generally. In contrast, for low-income families, prepaid 529 plans actually have had a built-in disincentive as saving in this manner could reduce the need-based aid for which their child may qualify (Ifill and McPherson 2004).

Additionally, constraints on middle-income groups have challenged the availability of funds to put towards educational savings. While middle-income families have participated at high rates in activities that demonstrate value in education (Napolitano et al. 2014), a recent Sallie Mae (2015b) study has found fewer middle-income families saving for college, down from 51\% in 2014 to $46 \%$ in 2015-the only income group to experience such a decline. Moreover, as the ownership of retirement accounts fell below 50\% in 2013 as part of a downward overall trend in all savings (Bricker et al. 2014), families have struggled to choose between focusing their savings on 
planning for college and their retirement (Napolitano et al. 2014). Overall, although families at all income levels may have similar desires and motivations for saving, income has been, not surprisingly, a main factor in whether parents actually have saved for a student's education.

\section{Research Questions}

Given these bodies of literature, we investigated the evidence that parents converted some of their cultural capital into financial capital for their children's college education, and further looked at the specific actions parents took by asking the following questions: To what extent were aspects of cultural capital related to parents taking financial planning action for their child's college education? To what extent were aspects of cultural capital related to the amount of savings reported? To what extent were aspects of cultural capital related to the specific type(s) of financial planning actions parents report taking?

To address these questions, we include in our study the factors reviewed above relating to college financial planning, along with basic demographic and education-related factors. We focused on parents' idealistic college aspirations for their child, their realistic expectations, and their involvement in both home- and school-based activities during their child's high school years. We explored potential conversion of these manifestations of cultural capital to financial capital for college, represented by a range of reported parental financial college preparations and the amount parents of $10^{\text {th }}$ graders saved for college. Overall, we predicted that higher levels of cultural capital would be associated with an increased likelihood of preparing financially for college, independent of income, thus demonstrating a conversion of capital.

\section{Method}

\section{Data}

Data were drawn from the US National Center for Education Statistics’ (NCES) 2002 Education Longitudinal Study's (ELS:2002) base year spring survey of the parent most familiar with the school situation of the sampled $10^{\text {th }}$ grade students. ELS:2002 was a particularly good dataset with which to investigate US parental financial planning issues since it was the only nationally representative dataset that included information about a wide range of possible financial planning activities. While other datasets included information about whether parents took action to financially prepare to contribute toward the cost of their child's college education and the amount they saved for this purpose, information about a range of specific strategies parents had taken was only available in ELS. The more recent national High School Longitudinal Survey only included a general question to parents about 
opening a college savings account, while ELS offered information about 13 financial planning actions parents might have taken.

This study used only the base year of ELS' longitudinal data collection, which was included in all subsequent data releases of ELS as well. This 2002 base year included surveys of both $10^{\text {th }}$ graders and their parents. Using a two-stage sampling process to achieve a nationally representative sample of students, 15,362 students from 752 schools participated, for an $87.3 \%$ weighted response rate. A total of 13,488 parents participated for an $87.5 \%$ weighted coverage rate. Multiple imputation to address missing data (covered in the subsection on correlation and missing data analysis below) on the $200210^{\text {th }}$ grade cohort resulted in a weighted analytic sample of 14,872 cases, not including parents of American Indian and multiracial students $(n=378)$ due to insufficient subpopulation sample sizes. ${ }^{4}$ Only parents of responding students were included in ELS:2002. Parent questionnaires were available in English or Spanish. Asian and Hispanic parent data were weighted because their children were oversampled during the second sampling stage of student participant selection (Ingels et al. 2004).

\section{Dependent Variables}

The dependent variables analyzed included whether parents reported planning financially for college in any manner, the US dollar amount of saving (as either zero dollars, $\leq \$ 10,000$, or $>\$ 10,000$ ), and participation in 13 types of specific financial preparation. These 13 preparations included starting a savings account, buying an insurance policy, buying savings bonds, investing in stocks or real estate, setting up a college investment fund, starting to work another job or adding hours, establishing another form of savings, reducing expenses, planning to reduce expenses, re-mortgaging property or taking out a home equity loan, planning to re-mortgage property or take out a home equity loan, having their tenth grader save, or participating in a state-sponsored college savings program. Even though several responses fell into similar categories of behavior (e.g., related to savings, investment, loan, or lifestyle), a principal components factor analysis of the 13 specific financial preparation actions did not reveal any good reduction of the number of variables by combining them into scales representing constructs. Parents appeared to pick and choose from across the range of actions in a variety of patterns, precluding data reduction. Therefore, analysis was conducted on all 13 actions separately.

\footnotetext{
${ }^{4}$ Results of all analyses using multiple imputation when restricting the sample to cases where parents completed a survey (not presented) are substantively similar to those reported here for the entire $10^{\text {th }}$ grade cohort. This reinforces the assumption that these missing parent data are either missing completely at random (MCAR) or missing at random (MAR) and can reasonably be imputed. For ease of interpretability, we present results for the full $10^{\text {th }}$ grade cohort.
} 


\section{Independent Variables}

Components of cultural capital investigated included the primary independent variables of parental aspirations and expectations, and home- and school-based parental involvement. The first two of these measured whether parents held the aspiration or expectation that their child would attain at least a bachelor's degree. The two parental involvement variables were derived from principal components factor analysis on a series of ten questions about parents' interactions with their child and their child's school. These variables did not reduce to one overall parental involvement construct, but naturally separated into home- and school-based constructs that also fit existing theory concerning parental involvement.

Variables shown to relate to parental college savings were controlled, including income, ${ }^{5}$ demographic, and education related variables. The demographic variables were age of the oldest parent, number of children in the family, student gender, parent ethnicity and primary language, and work status of the oldest parent. The education related variables were parental and grandparental education levels (the embodiment of a family's human capital), school type, whether the child has ever been held back in school, reading and math test scores (for standardized tests administered by NCES), and pre-first-grade program attendance.

This last variable, pre-first-grade program attendance, deserves special comment. While standard child grade advancement (e.g., never being held back) has been shown to correspond to higher parental college savings (Horn et al. 2003), analysis of educational impact has not extended before kindergarten. Given that participation in Head Start beginning in preschool has been positively connected to later school success, including lower grade retention, as well as higher reading ability and higher high school graduation rates (Reynolds et al. 2002), a connection between early educational experiences and subsequent parental college savings seemed plausible. The early childhood education variables used here included attendance in day care, nursery school, Head Start, and kindergarten.

\section{Correlation and Missing Data Analysis}

Correlation matrices were examined to check for highly correlated variables and to understand the relationships between variables. Only one pair of variables was so highly correlated as to cause concern: parental expectations and parental aspirations, which were correlated with a value of 0.58 . This relatively high correlation

\footnotetext{
${ }^{5}$ Given that including income in a separate model block with the cultural capital variables but without the other controls (results not presented) rarely substantially changed the resulting relationship between a cultural capital variable and our outcomes of interest, we present income in our control block for all analyses.
} 
was expected, since parents that realistically expect a bachelor's degree for their child are very likely also to desire that outcome. When we applied collinearity diagnostic tests to our models, specifically examining the variance inflation factor (VIF), to get a more precise understanding of variable relationships and where problems may exist, all VIF values were less than Allison's (1999) cautionary range of 2.5 or higher, including the values for parental expectations and parental aspirations. Given the unique information that might be gained by including them, and given the acceptable VIF values, these (and all other) variables were retained for analyses.

Multiple imputation addressed missing data in the sample. This is the most effective strategy for dealing with large amounts of missing data, resulting in precise, unbiased estimates (Allison 2002; Schafer and Graham 2002). While some demographic variables had almost no missing data, the variables for the 13 actions and the amount saved all had over $30 \%$ missing data, with a maximum of $34 \%$ for the amount saved. Only about $42 \%$ of the sample would have been retained under listwise deletion. ${ }^{6}$ Given that the largest fraction of missing information in any analysis conducted was $F M I=0.9$ for one of the financial actions, we chose to impute $m=100$ datasets (Graham et al. 2007). Imputations were generated through the chained equations approach (van Buuren 2012) using Stata's mi impute chained command. Although NCES offered single imputations for several variables, we used multiple imputation for all variables, and we also included all complex survey design variables when imputing (Manly and Wells 2015). Rubin's (1987) rules were used during analysis to obtain proper statistical results. We report the median across all imputed datasets for fit statistics that are not appropriately combined with Rubin's rules.

\section{Regression Analysis}

Using logistic regression, we first examined who engaged in any financial planning action. Second, using multinomial logistic regression, we investigated which independent variables were significant predictors of an amount saved of either $\leq \$ 10,000$, or $>\$ 10,000$, as compared to not saving at all (Long and Freese 2006; Treiman 2009). ${ }^{7}$ For both analyses, we utilized two variable blocks. We first included only variables representing parental

\footnotetext{
6 A comparison of results using multiple imputation and listwise deletion showed a reasonably good correspondence overall, although there were some differences. In particular, for the cultural capital variables, differences included parental expectations (for three out of 15 models) and parental home involvement (one out of 15). The factors showing the most differences overall were private school (five out of 15) and the number of kids (four out of 15).

${ }^{7}$ We conducted several alternate analyses for the amount saved to test the sensitivity of our results to the analysis model chosen. Ordinary least squares models for a pseudo-continuous amount saved variable, which likely violate the assumption of normality of errors due to the large number of zero values, produced results very similar in nature to the multinomial models presented, with only a few exceptions (e.g., attending private school was significant and parent age was not; $\left.\mathrm{R}^{2}=0.30\right)$. Given that the amount saved was collected as a categorical response set, we also considered ordered logistic regression. However, this specification failed the parallel regression assumption (via a
} 
aspirations, expectations, and involvement. The final block included all controls, representing income, demographic and education variables. In our third analysis, we analyzed each of the 13 individual financial preparations separately (via logistic regression) to evaluate whether the change in their odds of being utilized was significantly related to the independent variables, particularly those representing cultural capital.

\section{Limitations}

As with all secondary data analysis, this study was subject to data limitations. Several variables previously shown to affect college savings were not part of this data set, including the health of the household head, net worth and retirement savings amount. It was not clear from the data whether the family had exposure to postsecondary education through any older siblings of the $10^{\text {th }}$ grader, a possible motivating factor for financial action for subsequent children that we were unable to investigate. Information about plans for grandparents to contribute financially toward college costs also was not gathered although it may have had an impact on parental saving. While it was possible that these factors might have contributed error to the results via omitted variable bias, these items could not be controlled since they were not asked of the survey respondents.

The timing of these data also presented limitations. As discussed above, these were the most recent national data that contain information about parents' financial planning strategies for their children's' college education. Even so, these data were collected in 2002, over 10 years ago. In addition, the recession occurred since these data were collected, which may have altered the finances that families have available as well as their attitudes about what strategies they consider appropriate for college financing. While our results were nationally generalizable, generalizing them to the current financial climate would need to be done cautiously given these significant changes.

Our methods also had limitations. While they were appropriate for the research questions of this study, they were purely correlational, and causal relationships could not be assumed. There may be causes for these relationships that were not included in this study, and we do not claim causality from this design.

\section{Results}

Parents' aspirations for their child were generally higher than their expectations for their child's achievement, as expected (Table 1). Most parents in the study were White, native English-speaking, and had a child who attended public school and who went to some form of pre-first grade early childhood education. In most

Brant test) on which ordinal models rely (Long 1997). Multinomial logistic regression on all eight original categories did produce slightly more nuanced findings (e.g., particularly for parents who do not work and high school type), but the added complexity would not add substantially to the interpretation of our primary findings, and so we present more concise three-category results. 
families, the oldest parent worked full-time. In about $64 \%$ of families, neither parent had attained a bachelor's degree, and for about $74 \%$ of families, no grandparent was reported as having one. The "average" parents were around 46 years old, had two children, and had a family income of more than $\$ 60,000$. Descriptive statistics for parental involvement and student test scores were less easily interpreted because they were operationalized as standardized variables. However, with these and other variables, there was an obvious shift from the full sample to the sub-samples. For example, the sub-sample of parents who have taken financial action were more involved with their children's education in both home and school settings and had children with higher test scores.

(Place Table 1 about here.)

The first outcome examined was the parental survey response to the yes or no question: "Have you or your spouse/partner done anything specific in order to have some money for your tenth grader's education after high school?" The descriptive results in Table 1 indicate that about half of $10^{\text {th }}$ graders' parents responded positively. The average amount these parents had saved by $10^{\text {th }}$ grade was approximately $\$ 14,000$, as compared to about $\$ 7,000$ when all parents (including those who saved nothing) were considered. The descriptive results for each action in Table 1 show which activities were most common. By far the most common action was to start a savings account, which was done by $75 \%$ of parents who had taken some financial action, and $38 \%$ of all parents. The least common actions, at $12 \%$ or less for savers and $6 \%$ or less overall, were to re-mortgage property or to participate in a statesponsored college saving program (e.g., a 529 program).

\section{Cultural Capital and Taking Financial Planning Action}

Table 2 presents the results of analyzing predictors of whether parents reported taking any financial action. In Table 2, we first investigate the cultural capital variables, and then block in the control variables to form the full model. This approach allowed us to identify which aspects of cultural capital were related to financial planning decisions, as well as which relationships were better explained by other factors in the model, including income.

Table 2 presents odds ratios; values greater than one represent increases in the odds of taking action, and values less than one represent decreases in the odds of taking action. We focus this discussion on odds ratios rather than alternate representations such as marginal changes or predicted probabilities because odds ratios provide sufficient information for our purpose of investigating capital conversion. Importantly, given our large sample size, we consider findings throughout this paper statistically significant only at the .01 level or better.

(Place Table 2 about here.) 
Across both blocks, Table 2 shows several aspects of cultural capital were predictive of financial planning action. If parents were more involved in their child's education, they were more likely to take some financial planning actions, assuming all other variables were constant. Specifically, a one standard deviation increase in parents' involvement at school or at home was related to greater odds of financially planning for their children's education by a factor of 1.31 or 1.30 respectively in the full model, holding other variables constant. (While we do not repeat the phrase "holding other variables constant" throughout, all results from regression are subject to this stipulation.) In order to understand this one standard deviation change in involvement, recall that this corresponds to parents who took substantially more home- or school-based actions than most other parents. Our result clearly connects increases in involvement with greater odds of financial planning.

Table 2 also shows that, controlling for other aspects of cultural capital (including parental expectations), parental aspirations were not related to the likelihood of taking financial planning actions. However, parents with high realistic expectations were more likely to take some sort of action (controlling for aspirations). Specifically, parents who expected their child to achieve at least a bachelor's degree had odds of taking financial planning action that were 1.27 times higher than the odds of parents with lower educational expectations. Whether any parent had a bachelor's degree also was related, although any intergenerational effect on overall financial planning was only directly seen between parents and children, not grandparents.

\section{Cultural Capital and Savings Amount}

Table 3 shows the results of investigating the amount saved and presented multinomial logistic regression results comparing both amounts saved $\leq \$ 10,000$ and $>\$ 10,000$, as compared to not saving.

(Place Table 3 about here.)

Parental school and home involvement were aspects of cultural capital that were predictive of the amount that parents saved for their child's college education. However, income and our other controls fully explained the relationship between the amount saved for college and either parental expectations or aspirations. Income was predictive of the amount saved in the full model, although interestingly, as in Table 2, it did not have the largest effect size. Both forms of parental involvement had an effect on the odds of saving a large amount $(>\$ 10,000)$ by a factor of 1.34 , compared to not saving, while the effect of a $\$ 10,000$ increase in income was a slightly lower factor of 1.20. Income also had a smaller effect size than either parental involvement variable on smaller amounts of saving $(\leq \$ 10,000)$. For a $\$ 10,000$ increase in income, a family's odds of saving a small amount rose by a factor of 
1.06, while the corresponding odds ratios for a standard deviation change in school and home involvement rose by factors of 1.28 and 1.27 respectively.

Other variables also had substantive associations with the amount saved. Variables with the highest effect sizes were for a family's human capital. For parents with at least a bachelor's degree, odds increased by a factor of 1.31 of saving $\leq \$ 10,000$ and by a factor of 1.66 of saving $>\$ 10,000$ compared to not saving. The effect size of having at least one grandparent with a bachelor's degree was also larger than that of a $\$ 10,000$ increase in income for large amounts of saving $(>\$ 10,000)$ compared to no saving, as was the coefficient for sending a child to nursery school. Negative relationships included those between parents with more children and large amounts of saving ( $>\$ 10,000)$ compared to no saving, and between either the oldest parent not working or a child attending Catholic school and saving a small amount $(\leq \$ 10,000)$.

\section{Cultural Capital and Individual Actions}

Logistic regression was used to analyze the 13 individual financial actions that parents may have taken for their children's education. Summary results for these actions are shown in Table 4. To read the table, each column presents statistically significant odds ratio results sorted from left to right according to the number of significant variables in the model. The variables are sorted top to bottom by the number of financial planning actions to which they are related. That is, the top rows show the independent variables that are related to the most actions, and the left-most columns show the actions that are related to the most independent variables. Looking down the column for each action identifies variables associated with taking that action (i.e., more or less likely with p-value <.01). Additionally, the effect size of the odds ratios is shaded according to the key: Negative effects are horizontally lined, while positive effects are shaded in increasing levels of darkness chosen to emphasize different effect sizes within our cultural capital variables of interest and income (and the middle positive effect group has additional vertical lines to help distinguish between groups). Values are labeled only for cultural capital variables with particularly strong effects.

(Place Table 4 about here.)

Using Table 4 to identify the most influential variables, it became apparent that parental involvement in both its forms was the most predictive of taking financial planning action, and that income and parental education were also highly prominent. Parents with higher involvement had 10-30\% increased odds of taking almost all financial actions. As one example, a standard deviation increase in parental school involvement predicted a $28 \%$ 
increase in the odds of participating in a state-sponsored savings plan. A $\$ 10,000$ increase in income increased the odds of using nine planning strategies by $20 \%$ or less. Parents who had bachelor's degrees were more likely to have taken eight actions to prepare financially for their child's education by the $10^{\text {th }}$ grade, with greater than a $20 \%$ increase in the odds of almost all of these actions.

Delving further into these actions from Table 4, both forms of parental involvement were related to all of the financial planning actions except remortgaging (12 out of the 13 strategies). Greater income and sending a child to nursery school were related to parents being more likely to plan to remortgage their home or take out a home equity $\operatorname{loan}^{8}$ in preparation to pay for college. Parents with higher incomes were also more likely to have either savings bonds or a savings account, invest in a college fund, stocks or real estate, or a state-sponsored program, take out an insurance policy, plan to re-mortgage, or avail themselves of another form of savings. Highlighting actions where other aspects of cultural capital were significant, in addition to higher parental involvement and income, parents were more likely to open a savings account if they had higher educational expectations for their child, held a bachelor's degree, and sent their child to nursery school, and were less likely to do so if they had more children, sent their child to private school, and if the oldest parent did not work. Additionally, parental expectations had a relatively strong relationship with planning to or actually reducing expenses, as well as having a $10^{\text {th }}$ grader put aside earnings. Without going into detail about every strategy, it was notable that the highest effect size of any variable for any action was the only action for which parental aspirations was significant: investing in a college fund (with a factor of 2.08).

One caveat to this presentation is that we strictly use 0.01 as our level of statistical significance, and do not indicate substantive significance in this table except for values of cultural capital variables with the largest effect. A variable just barely statistically significant is included, whereas one found not significant at our selected level even by a small amount is not included, thus not representing the complete extent to which each variable predicts the outcome. In addition, the size of the coefficient, which is necessary for an understanding of the relative importance of the model's variables, is only included specifically for the cultural capital variables, being indicated more generally for other variables through the shaded groups. Therefore, Table 4 gives a useful, accessible picture of our

\footnotetext{
8 This may be an aberration though, as the sharp rise in home equity-based borrowing beginning in 2002 and lasting until 2006 that appears to be associated with the subsequent economic downturn may partially explain this result (Mian and Sufi 2009).
} 
results for the 13 models that is sufficient for conveying our results pertaining to understanding capital conversion. Given the amount of information in 13 models, such a summary of features relevant to this study is desirable. ${ }^{9}$

\section{Discussion}

As anticipated, parents appear to convert their cultural capital to financial capital in the form of financial planning for their child's college education. Our results show parents drew upon multiple aspects of embodied cultural capital when making decisions about taking financial action. Surprisingly, the relationship between income and the amount saved was similar (as we have operationalized the variables) to that of cultural capital factors. Both parental involvement and income extensively related to specific planning actions taken, but income had fewer statistically significant associations and they were not as strong as might be expected. All of the cultural capital variables related to at least some form of financial planning for college.

\section{Cultural Capital and Financial Action}

In response to our first research question, our initial logistic regression model explored what variables may predict whether or not parents of US $10^{\text {th }}$ grade students in 2002 had begun to prepare financially in some way for their child's postsecondary education. As expected, if at least one parent realistically expected that the child would attain a bachelor's degree, the parents were more likely to have initiated some financial action.

This is interesting first, because our descriptive results show that although about three-quarters of parents have this expectation for their children, only about half have actually begun engaging in financial planning. This is similar to a gap between expectations and saving behaviors recently reported for parents with children under age 18 (Sallie Mae 2015b). Second, although parental idealistic aspirations (i.e., desires) are related to four of the financial planning actions when considered on their own (results not shown), when the two related factors are included in the same model, the more realistic expectations are what is more predictive of parental behavior in all but investing in a college fund. Aspirations and expectations are not often considered in models simultaneously, but by doing so we showed that the desires that parents have for their children do not drive monetary behaviors. In other words, even if parents desire for children to go to college, their planning actions are typically more related to their more realistic estimation of the likelihood of such an outcome. Such results may connect to previous findings that students who

\footnotetext{
${ }^{9}$ The condensed information in Table 4 relevant for this study should be used in conjunction with the complete regression results to get a full understanding of the relationships between the variables. These results, as well as additional information about the variables themselves may be found in a supplemental file available from the authors upon request or from the website https://works.bepress.com/ryan_wells/36/
} 
expect to graduate from college were more likely to report parental financial contributions to their education (Elliott and Friedline 2013). It is also worth remembering that these results exist within an overall context of greater privilege, since parents who are college savers can be described as a more advantaged group overall, having greater income, more involvement, and greater educational attainment themselves than parents who have not taken financial action. These families' higher average expectations are consistent with already advantaged families seeing college as more feasible.

In response to our second research question, we investigated predictors of the amount of savings reported by parents when their child was in $10^{\text {th }}$ grade. While not all aspects of cultural capital were related, parental school and home involvement predicted the level of parents' savings for their child's college education. Notably, their influence on the amount saved was slightly larger than a $\$ 10,000$ increase in income. While this might be influenced by the way we coded these variables, it nonetheless illustrates the importance that cultural capital has the ability to play in affecting the opportunities afforded to students.

Of additional interest to researchers, although a student's academic achievement often relates to outcomes associated with education, it was not statistically significant as a predictor of parental savings. While perhaps surprising that parents wouldn't save more for higher achieving students, apparently parents who save do so to increase opportunity for their children, no matter their level of academic promise.

In response to our third research question, 13 financial planning actions were probed. Again, both parental school and home involvement were the most important predictors, both with relatively high and widespread effects among the 13 actions studied. Parental expectations and aspirations were also significant, although for fewer strategies than involvement. The nature of these strategies also differed: educational aspirations were associated with more aspirational investing, while educational expectations were associated with four strategies that were more conservative and practical, perhaps drawing upon a logical connection with their more realistic grounding.

Several variables were notable for their lack of predictive ability for these 13 actions. While the involvement variables were broadly relevant, aspirations were only predictive of investing in a college fund, indicating that what parents wanted a child to achieve was not a major driver in choosing financial planning vehicles, when controlling for other factors. Intergenerational effects typically stopped with the child's parents, although grandparental education level was predictive of long-term investing (e.g., a college fund, stocks, or real estate), as well as frugality. Children's test scores were more frequently not significant factors after controlling for 
all other variables in the models. Thus, for many actions, as with the amount saved, other variables (perhaps parental factors such as involvement, income, or education level) may drive financial planning behaviors more than the student's academic performance. Despite the potential increased planning horizon, older parents did not appear particularly advantageous for children, except when it came to certain forms of investing. This connection with investing may relate to our finding in Table 3 that older parents have slightly higher odds of having saved larger amounts, other factors constant. Whether a student was ever held back in school was not predictive of any of these outcomes, although this was significant in past research (Horn et al. 2003). Gender of the student was not predictive of how parents took financial action for future education, which matched recent research concerning gender differences in educational planning, but was different than historical trends concerning gender and education (Reynolds and Burge 2008).

Race/ethnicity or native language was a significant factor for six actions, but patterns in the results were elusive. Latino parents were less likely than Whites to have their child save, buy US savings bonds, or start a college fund. Blacks were more likely than Whites to take out an insurance policy, plan to or actually reduce expenses. Native English speakers were more likely to buy US savings bonds. The dissimilarities suggest that different strategies may appeal to parents of different characteristics, though conclusions were hard to draw.

\section{Capital Conversion}

Throughout our results, we found evidence consistent with capital conversion. Parental expectations and involvement may be thought of as components of a family's cultural capital and as factors that help to make up the student's habitus. Across our research questions, results imply that students in families with more cultural capital are more likely to benefit from its conversion into financial capital specifically for college. Regardless of family income, parental education, school attended, race/ethnicity, and the other variables in our models, these aspects of cultural capital allow families to confer advantages on their children via more extensive early financial planning for further education.

Of the cultural capital variables, the two forms of parental involvement were, by the number of models in which either is statistically significant, the most widely predictive factors for parental financial planning. Parents involved in their children's education at school (such as participation in a parent teacher organization or volunteering at school) or at home (such as helping with homework or attending activities outside of school 
together) were more likely to have planned for postsecondary education by $10^{\text {th }}$ grade, to have saved either a smaller or larger amount, and to have engaged in most of the financial planning actions studied.

Across all of our models, some other independent variables were consistently significant and also related to college financial planning. Not surprisingly, income was predictive of most of our outcomes, and in ways that would largely be expected. This is representative of the direct effect of family financial capital on educational planning, rather than the indirect influence of other forms of family capital on planning via the conversion to financial capital. The relative strength of non-financial variables is made partly visible in our results since a $\$ 10,000$ increase in family income was related to a smaller change in the amount saved than several non-financial variables. This may indicate that while having financial capital is important, a family's values, opportunities, and barriers (which are incorporated in and also affected by one's habitus) play at least an equivalent if not more significant role in determining how much a family saves for college.

Coleman's (1988) work on social capital raises an observation concerning one of our control variables. He suggested that the number of children in a family was an indicator of a lack of social capital because it represents "a dilution of adult attention to the child" (p. S111). In our models (Table 2), the number of children in a family was negatively related to taking any financial planning actions (each additional child predicts $11 \%$ lower odds of taking action) and to the amount of money saved (each additional child predicts approximately $22 \%$ lower odds of saving more than $\$ 10,000)$. These results may match Coleman's ideas of a lack of social capital for the child, or may alternatively be thought of as a dilution of parents' cultural capital. In other words, for families with equal levels of expectations, involvement, income, etc., those with more children may be able to devote less of those resources to any one child. The conversion of cultural capital to financial capital is perhaps more widely dispersed in such cases.

From a Bourdieuian perspective, our results support the notion that class structure is reproduced via social processes, here via financial planning for children's education. This may represent one facet of the hidden nature of that reproduction. Not only was income related to taking financial action, but even when controlling for income, the family's cultural capital was also related to preparing financially. In doing so, class advantage is maintained.

This maintenance of inequality is troubling in many ways, and potentially far-reaching in its consequences. The connection between income and financial planning for college is apparent, and therefore policies have been formulated to address it. Need-based financial aid is meant to close this gap, for example, offering students of different means more similar opportunities for college than would be otherwise possible. However, if other aspects 
of a student's habitus are equally or more influential for financial planning for college, similar policy interventions are not forthcoming to address this less visible gap.

While social class is not the primary predictor of these parental planning strategies per se, past research has shown that working class parents may see parental involvement differently than professional class parents, which was the main predictor identified in this study. Working class parents may place ultimate responsibility for educating their children on teachers instead of assuming that responsibility themselves. In such a climate, involvement can be seen as overreach or overstepping one's bounds. Alternately, professional class parents who see teachers as equals (or perhaps subordinate) view parental involvement as their role in the educational process (Lareau 1987 2011; Rowan-Kenyon et al. 2008). This example shows how subtle differences in habitus may have a ripple effect that permeates many aspects of the college transition. Such unequal ripples have the potential to propagate from aspirations, to college application, and on to enrollment and degree completion. One might also assume that if the student has children in the future that the intergenerational advantage may continue, particularly at higher levels of saving.

\section{Implications}

Our results have implications for theory and the use of theory when studying family financial planning and/or college going. We demonstrate that parents converted cultural capital that they had built up over time (in the form of dispositions toward college education and actions taken to involve themselves in their child's education) into financial capital for college for their children. Bourdieu (1986) discussed the reverse conversion of economic capital to cultural capital. Indeed, one can assume that the intergenerational transmission of advantage via the conversion of capital we have revealed may continue in precisely this way; students may benefit from the conversion of parental cultural capital to financial capital, and they may then convert this financial investment into their own cultural capital through the experiences and opportunities associated with a college education. That cultural capital may then be converted into savings for their own children's college education, and so on. This intergenerational process aligns with Bourdieuian notions of social reproduction, but such a fine grained look at this concept may serve as a framework in future research to study family savings or college related processes, as did Martin and Spenner (2009).

These phenomena around financial planning for college should be looked at through other frameworks of social inequality, which may also shed more light on the ways they are embedded with privilege. Given our findings, 
in combination with the notion that higher-class parents may use a number of "cumulatively crucial interventions" (Lareau, 2011, p. 341) for their children's success, frameworks of cumulative (dis)advantage seem promising (DiPrete and Eirich 2006) when examining college financial planning. Additionally, our findings support the notion that more privileged populations may benefit from qualitatively different educational experiences (e.g., advantages associated with savings for college) even though they get the same quantitative outcome (e.g., a high school education), which could directly be examined with the theory of Effectively Maintained Inequality (Lucas, 2001, 2009). In short, our findings suggest another aspect of maintained social inequality through education, and therefore deserve more research.

Our results also lead to a number of implications for both future research and policy. While we analyzed more detailed financial preparations than most previous studies of US college savings, specific education savings vehicles were not distinguished. For example, investments in a Coverdell Education Savings Account might be combined with alternate vehicles recommended by some financial planners, such as a Roth IRA (Higgins 2008), and with similar generic investment options in the response choice of "a college investment fund" (National Center for Education Statistics 2002, p. 28). The general nature of the response choices in ELS means that only general parental strategies can be evaluated. Additionally, the continued development of funding vehicles such as SEED programs may have implications particularly as savings vehicles for low-income parents (Johnson et al. 2010, Wikoff et al. 2015), but were not studied here. Future research data could distinguish further between general family saving that is intended for college and specific college savings vehicles.

The significance of grandparent education level (assuming that the parental education levels are the same) to larger amounts saved and to several strategies used is an indication that the family capital concept, and the conversion of that capital, may work across multiple generations, as described above. This may imply a multigenerational transmission of the understanding of the importance of early planning for students' postsecondary education. Future research might consider how this process happens, as well as other triple-generational effects in college planning and choice processes. For example, the effects of grandparents physically housing and being financially responsible for their grandchildren could be examined through a future intergenerational study. Also, the intergenerational transmission of class advantages is in line with prior findings that children whose parents have saved for college were more than three times more likely to have their own savings as well (Friedline 2012). Our result that $40 \%$ of parents who had taken financial action had their child set aside earnings, when combined with our 
result that grandparents' education level relates to higher amounts saved, may support the idea that dispositions toward college savings may be passed between generations in ways that serve to reinforce social reproduction.

Another angle for looking at family effects might be to consider whether closed or open social networks affect student opportunity and access to financial information. We know that students' engagement with their peers enables them to gather realistic information about college costs, increasing the likelihood of parental savings (Hossler and Vesper 1993). While we chose to investigate aspects of cultural capital, looking at family involvement from the perspective of social capital networks including extended family members or peers may provide interesting alternate perspectives on financial planning issues, particularly for cultures which value extended family highly, such as Latino or Hispanic groups (Calzada et al. 2013).

An intriguing set of results connects a child's earliest educational experiences to planning for college. Participation in nursery school is predictive of quite a few of our outcomes and may show that a propensity to further a child's education is at work from the earliest years through $10^{\text {th }}$ grade, and might be considered an early form of parental involvement in education. Alternatively, this early experience may have an effect on families that relates to greater understanding of the need to plan for continued education. Since parents typically pay for nursery school, perhaps the choice to spend money on this educational expense prompts parents to begin early action on longer-term educational expenses. Whether that might correspond to immediate early action, different actions taken over multiple years, or action starting years later is unclear without additional data. Perhaps depending on parents' dispositions toward financial risk and their understanding of the potential for compounding, this early consideration leads some, who we might imagine being more financially conservative, toward savings vehicles, and others, who might be willing to tolerate more risk, toward investment vehicles. It seems reasonable that those who are prompted to start early in their child's life will be able to take advantage of more years of compounding, resulting in greater amounts saved later on as seen here. Early awareness may also give parents the time to act on a strategy that depends partly on market rate fluctuations, like re-mortgaging a home. Additionally, it is interesting that sending a child to nursery school was more predictive of our outcomes than the later academic ability that child demonstrates. Given that a child's academic potential may not be apparent to parents during the early childhood period, this suggests that parental predispositions toward the value of extended education for any child, independent of demonstrated ability, may affect their choices and actions across decades. Whether this provides further support for 
Bourdieu's idea of slow conversion between the forms of capital is unclear but intriguing. Such issues and questions need greater theorizing and empirical study, but our results suggest they would be worth investigation.

Future analysis could explore whether family financial preparation or the amount saved are connected with higher levels of postsecondary enrollment, selective enrollment, or degree attainment, or how various forms of financial preparation relate to financial aid received at different socioeconomic strata. Distinctions in such outcomes between two- and four-year institutions could expand prior research already connecting parent contributions and degree completion differences between institution types (Nam and Ansong 2015). Additional research could look at what happens to children whose parents expect to send them to college but who have not taken any financial planning action by the time they were in $10^{\text {th }}$ grade. Another opportunity would be to look earlier for discernable trends in financial planning and amounts saved, although this would need to use other longitudinal datasets including financial information, since ELS begins in $10^{\text {th }}$ grade.

Our results may also inform various policies and practices concerning college planning. On the surface, knowing that the average amount saved by families is typically less than the amount needed to fully fund two or four years of college emphasizes the desirability of encouraging increased college savings by all groups, no matter what sector of higher education a child intends to pursue in order to increase access across the board. Delving deeper though, in many ways, we confirm the assumptions of many policies and practices that low-income and firstgeneration students, as well as their families, are likely to need extra assistance and support in order to navigate the college planning and choice processes. However, our results also indicate that broader "family" factors may be valuable to consider.

We reinforce encouragement for those framing financial planning policies to strive to put information and support in place specifically for those least likely to participate. Involved parents of all incomes utilized more common strategies like savings bonds, insurance policies, investing, reducing expenses, and savings accounts, so dissemination efforts for less involved parents that discuss these options may resonate broadly as a starting point. Such findings connect to underrepresented demographic groups as well; students with disabilities were found to be three times more likely to enroll in a postsecondary school if their parents had bonds for college (Cheatham and Elliott 2013), so special education advocates might consider the possible benefits of providing savings information to help more such families conduct financial college planning earlier. Reaching out to parents of large families represents another area of opportunity, and while speculative, perhaps it would be helpful to utilize family 
connections through early education programs to present easier strategies and the advantages of compounding small amounts starting when children are young.

More investigation is also needed about state-sponsored savings programs, one of the least commonly used actions in our study. These were still relatively new when these data were collected, and reliable usage trends deserve continued investigation. These programs appear to be growing in popularity, growing from $6 \%$ of families in 2002 to 27\% in 2015 (Sallie Mae 2015b). Additionally, SEED programs across the nation, which were not available when ELS data was collected, focus on college saving processes through incentives such as waived fees to enroll, information about saving, and dollar matching, though many still remain underutilized for low-income parents (Johnson et al. 2010; Wikoff et al. 2015; Williams Shanks et al. 2014;). Short of significant decreases in overall student costs, any financial aid or related policies that intend to increase equity (i.e., diminish the social reproduction inherent in college financial planning) ought to give advantages to students who need them that are proportional to the disadvantages they experience, made apparent by these results.

A college education is becoming ever more important to a number of life outcomes in the US, but with increasing tuition, early financial planning is of greater importance. Our results help to understand what parents have done such planning, and what forms their financial actions have taken. We have exposed some differences in financial planning based on specific components of family cultural capital, specifically positive college expectations and parental involvement. We have shown that families who possess such cultural capital may convert it to financial capital for college, reinforcing societal inequality. By and large, those students with the fewest of these familial resources are disadvantaged in the area of financial planning, to add yet another component to the disadvantages they experience in the college transition process and contributing to social reproduction. Further research to uncover the more detailed processes at work, and policy initiatives to balance inequities in the college opportunity structure should expand and continue this type of work.

Compliance with Ethical Standards:

Ethical approval: This article does not contain any studies with human participants performed by any of the authors. 


\section{References}

Allison, P. D. (1999). Multiple regression: A primer. Thousand Oaks, CA: Pine Forge Press.

Allison, P. D. (2002). Missing data. Thousand Oaks, CA: Sage Publications.

Becker, G. S. (1993). Human capital: A theoretical and empirical analysis, with special reference to education (3rd ed.). Chicago: University of Chicago Press.

Berger, J. B. (2000). Optimizing capital, social reproduction, and undergraduate persistence: A sociological perspective. In J. M. Braxton (Ed.), Reworking the student departure puzzle (pp. 95-124). Nashville, TN: Vanderbilt University Press.

Bourdieu, P. (1971). Intellectual field and creative project. In M. F. D. Young (Ed.), Knowledge and control: New directions for the sociology of education (pp. 161-188). London: Collier-Macmillan.

Bourdieu, P. (1986). The forms of capital. In J. G. Richardson (Ed.), Handbook of theory and research for the sociology of education (pp. 241-258). New York: Greenwood.

Bourdieu, P., \& Passeron, J. C. (1977). Reproduction in education, society, and culture (R. Nice, Trans.). Beverly Hills, CA: Sage Publications.

Bricker J., Dettling, L. J., Henriques, A., Hsu, J. W., Moore, K. B., Sabelhaus, J., Thompson, J. \& Windle, R. A. (2014). Changes in U.S. family finances from 2010 to 2013: Evidence from the survey of consumer finances. Federal Reserve Bulletin. Retrieved from http://www.federalreserve.gov/pubs/bulletin/2014/pdf/scf14.pdf

Calzada, E. J., Tamis-LeMonda, C. S., \& Yoshikawa, H. (2013). Familismo in Mexican and Dominican families from low-income, urban communities. Journal of Family Issues, 34(12), 1696-1724. doi:10.1177/0192513X12460218

Cheatham, G. A. \& Elliott, W. (2013). The effects of family college savings on postsecondary school enrollment rates of students with disabilities. Economics of Education Review, 33, 95-111. doi:10.1016/j.econedurev.2012.09.011

Coleman, J. S. (1988). Social capital in the creation of human capital. American Journal of Sociology, 94, S95-S121. Retrieved from http://www.jstor.org/stable/2780243

Coleman, J. S. (1990). Foundations of social theory. Cambridge, MA: Harvard University Press. 
DeVaney, S. A., Anong, S. T., \& Whirl, S. E. (2007). Household savings motives. Journal of Consumer Affairs, 41(1), 174-186. doi:10.1111/j.1745-6606.2006.00073.x

DeVaney, S. A., \& Chien, Y.W. (2002). Children's education as the most important savings goal. Journal of Family and Consumer Sciences, 94(1), 64-70. Retrieved from http://search.proquest.com/docview/218195833

DiPrete, T. A., \& Eirich, G. M. (2006). Cumulative advantage as a mechanism for inequality: A review of theoretical and empirical developments. Annual Review of Sociology, 32, 271-297.

Dynarski, S. (2004). Who benefits from the education saving incentives? Income, educational expectations and the value of the 529 and Coverdell. National Tax Journal, 57(2), 359-383.

Elliott, W. \& Friedline, T. (2013). "You pay your share, we'll pay our share:” The college cost burden and the role of race, income, and college assets. Economics of Education Review, 33, 134-153. doi:10.1016/j.econedurev.2012.10.001

Engberg, M. E. \& Allen, D. J. (2011). Uncontrolled destinies: Improving opportunity for low-income students in American higher education. Research in Higher Education, 52(8), 786-807. doi:10.1007/s11162-011-9222-7

Fan, X. T., \& Chen, M. (2001). Parental involvement and students' academic achievement: A meta-analysis. Educational Psychology Review, 13(1), 1-22. doi: 10.1023/A:1009048817385

Friedline, T. (2012). Predicting children's savings: The role of parents' savings for transferring financial advantage and opportunities for financial inclusion. Children and Youth Services Review, 34, 144-154. doi:10.1016/j.childyouth.2011.09.010

Graham, J. W., Olchowski, A. E., \& Gilreath, T. D. (2007). How many imputations are really needed? Some practical clarifications of multiple imputation theory. Prevention Science, 8, 206-213. doi:10.1007/s11121007-0070-0

Grolnick, W. S., Benjet, C., Kurowski, C. O., \& Apostoleris, N. H. (1997). Predictors of parent involvement in children's schooling. Journal of Educational Psychology, 89(3), 538-548. doi:10.1037/0022-0663.89.3.538

Herrold, K., \& O'Donnell, K. (2008). Parent and family involvement in education, 2006-07 school year, from the National Household Education Surveys Program of 2007: First look (NCES No. 2008-050). Washington, DC: National Center for Education Statistics. 
Higgins, T. (2008). Pay for college without sacrificing your retirement: A guide to your financial future. Point Richmond, CA: Bay Tree Publishing.

Hoover-Dempsey, K. V., \& Sandler, H. M. (1997). Why do parents become involved in their children's education? Review of Educational Research, 67(1), 3-42. Retrieved from http://www.jstor.org/stable/1170618

Horn, L. J., Chen, X., \& Chapman, C. (2003). Getting ready to pay for college: What students and their parents know about the cost of college tuition and what they are doing to find out (NCES Statistical Analysis Report No. 2003-030). Washington, DC: National Center for Education Statistics.

Hossler, D. \& Vesper, N. (1993). An exploratory study of the factors associated with parental saving for postsecondary education. The Journal of Higher Education, 64(2), 140-165. doi:10.2307/2960027

Ifill, R. M., \& McPherson, M. S. (2004). When saving means losing: Weighing the benefits of college savings plans. Indianapolis, IN: Lumina Foundation for Education.

Immerwahr, J. (2000). Great expectations: How the public and parents--White, African American and Hispanic-view higher education (No. R-00-2). San Jose, CA: National Center for Public Policy and Higher Education and Public Agenda.

Ingels, S. J., Pratt, D. J., Rogers, J. E., Siegel, P. H., Stutts, E. S., \& Owings, J. A. (2004). Education longitudinal study of 2002: Base year data file user's manual (NCES No. 2004-405). Washington, DC: National Center for Education Statistics.

Jennings, B. M., \& Olivas, M. A. (2000). Prepaying and saving for college: Opportunities and issues (Policy Perspectives No. 3). Washington, DC: College Board.

Johnson, T., Adams, D., Kim, J. S. (2010). Mapping the perspectives of low-income parents in a children's college savings account program. Children and Youth Services Review, 32, 129-136. doi:10.1016/j.childyouth.2009.08.008.

Kim, Y. \& Sherraden, M. (2011). Do parental assets matter for children's educational attainment?: Evidence from mediation tests. Children and Youth Services Review, 33, 969-979. doi:10.1016/j.childyouth.2011.01.003

Lareau, A. (1987). Social class differences in family-school relationships. Sociology of Education, 60(2), 73-85.

Lareau, A. (2011). Unequal childhoods: Class, race, and family life. Berkley, CA: University of California Press.

Lin, N. (2001). Building a network theory of social capital. In N. Lin, K. S. Cook \& R. S. Burt (Eds.), Social capital: Theory and research (pp. 3-29). New York: Aldine de Gruyter. 
Lippman, L., Guzman, L., Keith, J. D., Kinukawa, A., Shwalb, R., \& Tice, P. (2008). Parent expectations and planning for college (NCES Statistical Analysis Report No. 2008-079). Washington, DC: National Center for Education Statistics.

Long, J. S. (1997). Regression models for categorical and limited dependent variables. Thousand Oaks, CA: Sage Publications.

Long, J. S., \& Freese, J. (2006). Regression models for categorical dependent variables using Stata. College Station, TX: Stata Press.

Lucas, S. R. (2001). Effectively maintained inequality: Education transitions, track mobility, and social background effects. American Journal of Sociology, 106(6), 1642-1690.

Lucas, S. R. (2009). Stratification theory, socioeconomic background, and educational attainment. Rationality and Society, 21(4), 459 -511. doi:10.1177/1043463109348987

Luna de la Rosa, M. (2006). Is opportunity knocking?: Low-income students' perceptions of college and financial aid. American Behavioral Scientist, 49(12), 1670-1686. doi:10.1177/0002764206289139

Manly, C., \& Wells, R. (2015). Reporting the use of multiple imputation for missing data in higher education research. Research in Higher Education, 56(4), 397-409. doi:10.1007/s11162-014-9344-9

Martin, N., \& Spenner, K. (2009). Capital conversion and accumulation: A social portrait of legacies at an elite university. Research in Higher Education, 50(7), 623-648. doi:10.1007/s11162-009-9136-9

McDonough, P. M. (1997). Choosing colleges: How social class and schools structure opportunity. Albany, NY: State University of New York Press.

McDonough, P. M. (1998). Structuring college opportunities: A cross-case analysis of organizational cultures, climates, and habiti. In C. A. Torres \& T. A. Mitchell (Eds.), Sociology of education: Emerging perspectives (pp. 181-210). Albany, NY: State University of New York Press.

McDonough, P. M., Antonio, A. L., \& Horvat, E. M. (1997). College choice as capital conversion and investment: A new model. Association for the Study of Higher Education Annual Meeting Paper. Retrieved from the EBSCOhost ERIC database.

Mian, A. R., \& Sufi, A. (2009). House prices, home equity-based borrowing, and the U.S. household leverage crisis (NBER Working Paper No. 15283). Cambridge, MA: National Bureau of Economic Research. 
Nam, J. \& Ansong, D. (2015). The effects of a dedicated education savings account on children's college graduation. Economics of Education Review, 48, 198-207. doi:10.1016/j.econedurev.2015.07.004

Napolitano, L. J., Pacholok, S., \& Furstenberg, F. F. (2014). Educational aspirations, expectations, and realities for middle-income families. Journal of Family Issues, 35(9), 1200-1226. doi:10.1177/0192513X13479334

National Center for Education Statistics. (2002). Education longitudinal study of 2002: Parent questionnaire base year. Retrieved from U.S. Department of Education Web site: http://nces.ed.gov/surveys/els2002/pdf/ParentQ_baseyear.pdf

Paulsen, M. B., \& St. John, E. P. (2002). Social class and college costs: Examining the financial nexus between college choice and persistence. Journal of Higher Education, 73(2), 189-236. doi:10.1353/jhe.2002.0023

Perna, L. W. (2000). Differences in the decision to attend college among African-Americans, Hispanics, and whites. Journal of Higher Education, 71(2), 117-141. doi:10.2307/2649245

Perna, L. W. (2006). Understanding the relationship between information about college prices and financial aid and students' college-related behaviors. American Behavioral Scientist, 49(12), 1620-1635. doi:10.1177/0002764206289144

Perna, L. W., \& Titus, M. A. (2005). The relationship between parental involvement as social capital and college enrollment: An examination of racial/ethnic group differences. Journal of Higher Education, 76(5), 485518. doi:10.1353/jhe.2002.0036

Portes, A. (1998). Social capital: Its origins and applications in modern sociology. Annual Review of Sociology, 24, 1-24. doi:10.1146/annurev.soc.24.1.1

Putnam, R. D. (2000). Bowling alone: The collapse and revival of American community. New York: Simon \& Schuster.

Reyes, J. W. (2008). College financial aid rules and the allocation of savings. Education Economics, 16(2), $167-189$. doi:10.1080/09645290701383605

Reynolds, J. R., \& Burge, S. W. (2008). Educational expectations and the rise in women's post-secondary attainments. Social Science Research, 37, 485-499. doi:10.1016/j.ssresearch.2007.09.002

Reynolds, A. J., Temple, J. A., Robertson, D. L., \& Mann, E. A. (2002). Age 21 cost-benefit analysis of the Title I Chicago Child-Parent Centers (Discussion Paper No. 1245-02). Madison: University of WisconsinMadison, Insttute for Research on Poverty. 
Rowan-Kenyon, H., Bell, A. D., \& Perna, L. W. (2008). Contextual influences on parental involvement in college going. Journal of Higher Education, 79(5), 564-586.

Rubin, D. B. (1987). Multiple imputation for nonresponse in surveys. New York: Wiley.

Sallie Mae (2015a). How America pays for college 2015: Sallie Mae's national study of college students and parents. Retrieved from http://news.salliemae.com/files/doc_library/file/HowAmericaPaysforCollege2015FNL.pdf .

Sallie Mae (2015b). How America saves for college 2015: Sallie Mae's national study of parents with children under age 18. Retrieved from https://salliemae.newshq.businesswire.com/files/doc_library/file/HowAmericaSaves2015_FINAL.pdf .

Schafer, J. L., \& Graham, J. W. (2002). Missing data: Our view of the state of the art. Psychological Methods, 7(2), 147-177. doi:10.1037//1082-989X.7.2.147

Smart, J. C. (2005). Attributes of exemplary research manuscripts employing quantitative analyses. Research in Higher Education, 46(4), 461-477. doi:10.1007/s11162-005-2970-5

Song, H. \& Elliott, W. (2012). The effects of parents' college savings on college expectations and Hispanic youth's four-year college attendance. Children and Youth Services Review, 34(9), 1845-1852. doi:10.1016/j.childyouth.2012.05.022

Swartz, D. (1997). Culture and power: The sociology of Pierre Bourdieu. Chicago: University of Chicago Press.

Treiman, D. J. (2009). Quantitative data analysis: Doing social research to test ideas. San Francisco: Jossey-Bass.

Trent, W. T., Lee, H. S., \& Owens-Nicholson, D. (2006). Perceptions of financial aid among students of color: Examining the role(s) of self-concept, locus of control, and expectations. American Behavioral Scientist, 49(12), 1739-1759. doi:10.1177/0002764206289146

van Buuren, S. (2012). Flexible imputation of missing data. Boca Raton, FL: CRC Press.

Walpole, M. (2007). Economically and educationally challenged students in higher education: Access to outcomes. ASHE Higher Education Report, 33(3).

Wells, R. S. (2008). Social and cultural capital, race and ethnicity, and college student retention. Journal of College Student Retention: Research, Theory and Practice, 10(2), 103-128. 
Wikoff, N., Huan, J., Kim, Y., \& Sherraden, M. (2015). Material hardship and 529 college savings plan participation: The mitigating effects of Child Development Accounts. Social Science Research, 50, 189202, doi:10.1016/j.ssresearch.2014.11.017

Williams Shanks, T.R., Leyda Nicoll, K, \& Johnson, T. (2014). Assets and African Americans: Attempting to capitalize on hopes for children through college savings accounts. Review of Black Political Economy, 41(3), 337-356. doi:10.1007/s12114-014-9185-y

Yilmazer, T. (2008). Saving for children's college education: An empirical analysis of the trade-off between the quality and quantity of children. Journal of Family and Economic Issues, 29(2), 307-324. doi:10.1007/s10834-008-9105-z 
Table 1.

Estimated (weighted) means and standard errors of the estimates

\begin{tabular}{|c|c|c|c|c|c|c|}
\hline & $\begin{array}{r}\mathrm{M} \\
\text { full } \\
\end{array}$ & $\begin{array}{l}\text { of } \\
\text { nple }\end{array}$ & \multicolumn{2}{|c|}{$\begin{array}{c}\text { Mean of } \\
\text { parents who have } \\
\text { NOT taken financial } \\
\text { action }\end{array}$} & \multicolumn{2}{|c|}{$\begin{array}{c}\text { Mean of } \\
\text { parents who have } \\
\text { taken some financial } \\
\text { action }\end{array}$} \\
\hline \multicolumn{7}{|c|}{ Cultural capital independent variables of interest } \\
\hline Parental aspirations ( $\geq$ bachelor's) & 0.86 & $(<0.01)$ & 0.82 & $(0.01)$ & 0.90 & $(0.01)$ \\
\hline Parental expectations ( $\geq$ bachelor's) & 0.72 & $(0.01)$ & 0.65 & $(0.01)$ & 0.79 & $(0.01)$ \\
\hline Parental involvement - school & -0.02 & $(0.05)$ & -0.21 & $(0.05)$ & 0.16 & $(0.05)$ \\
\hline Parental involvement - home & -0.04 & $(0.05)$ & -0.22 & $(0.05)$ & 0.14 & $(0.05)$ \\
\hline \multicolumn{7}{|c|}{ Control variables } \\
\hline Income (in $\$ 10,000$ ) & 6.22 & $(0.10)$ & 4.41 & $(0.07)$ & 7.96 & $(0.15)$ \\
\hline Parent age & 46 & $(<1)$ & 45 & $(<1)$ & 47 & $(<1)$ \\
\hline Number of children & 2.46 & $(0.02)$ & 2.57 & $(0.02)$ & 2.36 & $(0.02)$ \\
\hline Female & 0.50 & $(0.01)$ & 0.50 & $(0.01)$ & 0.50 & $(0.01)$ \\
\hline White & 0.66 & $(0.01)$ & 0.60 & $(0.01)$ & 0.72 & $(0.01)$ \\
\hline Asian & 0.04 & $(<0.01)$ & 0.04 & $(<0.01)$ & 0.04 & $(<0.01)$ \\
\hline Black & 0.15 & $(0.01)$ & 0.16 & $(0.01)$ & 0.14 & $(0.01)$ \\
\hline Latino & 0.15 & $(0.01)$ & 0.20 & $(0.01)$ & 0.10 & $(0.01)$ \\
\hline Parent native English speaker & 0.85 & $(0.01)$ & 0.80 & $(0.01)$ & 0.89 & $(0.01)$ \\
\hline Parent works full-time & 0.77 & $(0.01)$ & 0.72 & $(0.01)$ & 0.81 & $(0.01)$ \\
\hline Parent works part-time & 0.08 & $(<0.01)$ & 0.09 & $(<0.01)$ & 0.07 & $(<0.01)$ \\
\hline Parent does not work & 0.16 & $(<0.01)$ & 0.19 & $(0.01)$ & 0.13 & $(0.01)$ \\
\hline Parent has bachelor's & 0.36 & $(0.01)$ & 0.24 & $(0.01)$ & 0.49 & $(0.01)$ \\
\hline Grandparent has bachelor's & 0.26 & $(0.01)$ & 0.19 & $(0.01)$ & 0.33 & $(0.01)$ \\
\hline Public school & 0.92 & $(<0.01)$ & 0.95 & $(<0.01)$ & 0.90 & $(<0.01)$ \\
\hline Catholic school & 0.04 & $(<0.01)$ & 0.03 & $(<0.01)$ & 0.06 & $(<0.01)$ \\
\hline Private school & 0.03 & $(<0.01)$ & 0.02 & $(<0.01)$ & 0.04 & $(<0.01)$ \\
\hline Student held back & 0.13 & $(<0.01)$ & 0.16 & $(0.01)$ & 0.11 & $(0.01)$ \\
\hline Test score (std) & 0.01 & $(0.02)$ & -0.20 & $(0.02)$ & 0.2 & $(0.02)$ \\
\hline Daycare & 0.36 & $(0.01)$ & 0.32 & $(0.01)$ & 0.41 & $(0.01)$ \\
\hline Nursery school & 0.59 & $(0.01)$ & 0.50 & $(0.01)$ & 0.67 & $(0.01)$ \\
\hline Head Start & 0.19 & $(0.01)$ & 0.23 & $(0.01)$ & 0.15 & $(0.01)$ \\
\hline Kindergarten & 0.96 & $(<0.01)$ & 0.95 & $(<0.01)$ & 0.97 & $(<0.01)$ \\
\hline
\end{tabular}


Table 1 (continued).

Estimated (weighted) means and standard errors of the estimates

\begin{tabular}{|c|c|c|c|c|c|c|}
\hline & \multicolumn{2}{|c|}{$\begin{array}{c}\text { Mean of } \\
\text { full sample }\end{array}$} & \multicolumn{2}{|c|}{$\begin{array}{c}\text { Mean of } \\
\text { parents who have } \\
\text { NOT taken financial } \\
\text { action } \\
\end{array}$} & \multicolumn{2}{|c|}{$\begin{array}{c}\text { Mean of } \\
\text { parents who have } \\
\text { taken some financial } \\
\text { action }\end{array}$} \\
\hline \multicolumn{7}{|c|}{ Dependent variables } \\
\hline Any financial action taken & 0.51 & $(0.01)$ & -- & -- & -- & -- \\
\hline Amount saved (\$) & 7,290 & $(230)$ & -- & -- & 14,310 & (350) \\
\hline Savings account & 0.38 & $(0.01)$ & -- & -- & 0.75 & $(0.01)$ \\
\hline Plan to reduce other expenses & 0.27 & $(0.01)$ & -- & -- & 0.54 & $(0.01)$ \\
\hline Stocks or real estate investment & 0.26 & $(0.01)$ & -- & -- & 0.52 & $(0.01)$ \\
\hline Reduced other expenses & 0.21 & $(<0.01)$ & -- & -- & 0.41 & $(0.01)$ \\
\hline Had $10^{\text {th }}$ grader put aside earnings & 0.20 & $(0.01)$ & -- & -- & 0.40 & $(0.01)$ \\
\hline Savings bonds & 0.19 & $(<0.01)$ & -- & -- & 0.37 & $(0.01)$ \\
\hline Insurance policy & 0.18 & $(<0.01)$ & -- & -- & 0.36 & $(0.01)$ \\
\hline College investment fund & 0.16 & $(<0.01)$ & -- & -- & 0.32 & $(0.01)$ \\
\hline Another form of savings & 0.16 & $(<0.01)$ & -- & -- & 0.31 & $(0.01)$ \\
\hline Another job and/or more hours & 0.11 & $(<0.01)$ & -- & -- & 0.23 & $(0.01)$ \\
\hline Plan to re-mortgage/home eq. loan & 0.07 & $(<0.01)$ & -- & -- & 0.15 & $(0.01)$ \\
\hline savings program & 0.06 & $(<0.01)$ & -- & -- & 0.12 & $(0.01)$ \\
\hline Re-mortgage or home equity loan & 0.05 & $(<0.01)$ & -- & -- & 0.10 & $(<0.01)$ \\
\hline Observations & 14,872 & & 7,056 & & 7,816 & \\
\hline
\end{tabular}

Note: Standard errors in parentheses. US dollars used. 
Table 2 .

Predictors of whether parents took any financial planning action - logistic regression models, odds ratios reported

\begin{tabular}{|c|c|c|c|c|}
\hline \multirow{2}{*}{$\begin{array}{l}\text { Variables } \\
\text { Parental aspirations ( } \geq \text { bachelor's })\end{array}$} & \multicolumn{2}{|c|}{ Cultural capital } & \multicolumn{2}{|c|}{ and Controls } \\
\hline & 1.202 & $(0.119)$ & 1.033 & $(0.107)$ \\
\hline Parental expectations ( $\geq$ bachelor's) & $1.562 * * *$ & $(0.115)$ & $1.272 * *$ & $(0.097)$ \\
\hline Parental involvement - school & $1.452 * * *$ & $(0.038)$ & $1.308 * * *$ & $(0.040)$ \\
\hline Parental involvement - home & $1.451 * * *$ & $(0.037)$ & $1.298 * * *$ & $(0.040)$ \\
\hline Income (in $\$ 10,000$ ) & & & $1.119 * * *$ & $(0.010)$ \\
\hline Parent age & & & 1.007 & $(0.004)$ \\
\hline Number of children & & & $0.890 * * *$ & $(0.021)$ \\
\hline Female & & & 0.960 & $(0.051)$ \\
\hline \multicolumn{5}{|l|}{ Race/ethnicity (vs. White) } \\
\hline Asian & & & 1.297 & $(0.186)$ \\
\hline Black & & & $1.172 *$ & $(0.094)$ \\
\hline Latino & & & 0.921 & $(0.096)$ \\
\hline Parent native English speaker & & & 1.179 & $(0.132)$ \\
\hline \multicolumn{5}{|l|}{ Parent work status (vs. full-time) } \\
\hline Parent works part-time & & & 0.854 & $(0.082)$ \\
\hline Parent does not work & & & $0.849 *$ & $(0.066)$ \\
\hline Parent has bachelor's & & & $1.435 * * *$ & $(0.088)$ \\
\hline Grandparent has bachelor's & & & $1.147 *$ & $(0.075)$ \\
\hline \multicolumn{5}{|l|}{ High school type (vs. public) } \\
\hline Catholic school & & & 0.869 & $(0.066)$ \\
\hline Private school & & & 0.833 & $(0.091)$ \\
\hline Student held back & & & 1.035 & $(0.089)$ \\
\hline Test score (std) & & & 1.062 & $(0.034)$ \\
\hline Daycare & & & 1.086 & $(0.058)$ \\
\hline Nursery school & & & $1.168 * *$ & $(0.069)$ \\
\hline Head Start & & & 0.979 & $(0.073)$ \\
\hline Kindergarten & & & $1.321 *$ & $(0.185)$ \\
\hline Constant & $0.658 * * *$ & $(0.054)$ & $0.226 * * *$ & $(0.061)$ \\
\hline Observations & \multicolumn{2}{|c|}{14,872} & \multicolumn{2}{|c|}{14,872} \\
\hline Log-likelihood & \multicolumn{2}{|c|}{$-2,166,642$} & \multicolumn{2}{|c|}{$-1,990,037$} \\
\hline McFadden's Adjusted R ${ }^{2}$ & \multicolumn{2}{|c|}{0.061} & \multicolumn{2}{|c|}{0.137} \\
\hline F-adj. Mean Residual [p-value] & \multicolumn{2}{|c|}{$0.815[0.603]$} & \multicolumn{2}{|c|}{$1.222[0.280]$} \\
\hline
\end{tabular}

Note: Standard errors in parentheses. $* * * \mathrm{p}<0.001, * * \mathrm{p}<0.01, * \mathrm{p}<0.05$ 
Table 3.

Predictors of the amount parents saved for college - multinomial logistic regression models, compared to $\$ 0$ saved

\begin{tabular}{|c|c|c|c|c|c|c|c|c|}
\hline \multirow{3}{*}{$\begin{array}{l}\text { Variables } \\
\text { Parental aspirations }(\geq \mathrm{BA})\end{array}$} & \multicolumn{4}{|c|}{ Cultural capital } & \multicolumn{4}{|c|}{ and Controls } \\
\hline & \multicolumn{2}{|c|}{$\leq \$ 10,000$} & \multicolumn{2}{|c|}{$>\$ 10,000$} & \multicolumn{2}{|c|}{$\leq \$ 10,000$} & \multicolumn{2}{|c|}{$>\$ 10,000$} \\
\hline & 1.134 & $(0.121)$ & $1.629 * *$ & $(0.276)$ & 1.040 & $(0.113)$ & 1.256 & $(0.234)$ \\
\hline Parental expectations ( $\geq$ BA) & $1.289^{* *}$ & $(0.105)$ & $2.028 * * *$ & $(0.219)$ & $1.197 *$ & $(0.100)$ & $1.281 *$ & $(0.157)$ \\
\hline Parental involvement - school & $1.376 * * *$ & $(0.060)$ & $1.552 * * *$ & $(0.112)$ & $1.283 * * *$ & $(0.052)$ & $1.342 * * *$ & $(0.052)$ \\
\hline Parental involvement - home & $1.357 * * *$ & $(0.059)$ & $1.581 * * *$ & $(0.114)$ & $1.270 * * *$ & $(0.052)$ & $1.339 * * *$ & $(0.051)$ \\
\hline Income (in $\$ 10,000)$ & & & & & $1.062 * * *$ & $(0.011)$ & $1.196 * * *$ & $(0.013)$ \\
\hline Parent age & & & & & 1.001 & $(0.005)$ & $1.015^{* *}$ & $(0.006)$ \\
\hline Number of children & & & & & $0.940 *$ & $(0.024)$ & $0.775^{* * *}$ & $(0.029)$ \\
\hline Female & & & & & 0.907 & $(0.052)$ & 1.011 & $(0.069)$ \\
\hline \multicolumn{9}{|l|}{ Race/ethnicity (vs. White) } \\
\hline Asian & & & & & 1.195 & $(0.189)$ & 1.358 & $(0.241)$ \\
\hline Black & & & & & $1.181 *$ & $(0.098)$ & 0.854 & $(0.109)$ \\
\hline Latino & & & & & 0.932 & $(0.108)$ & $0.710^{*}$ & $(0.115)$ \\
\hline Parent native English speaker & & & & & 1.224 & $(0.155)$ & 1.141 & $(0.180)$ \\
\hline \multicolumn{9}{|l|}{ Parent work status (vs. full-time) } \\
\hline Parent works part-time & & & & & $0.795^{*}$ & $(0.088)$ & 0.982 & $(0.134)$ \\
\hline Parent does not work & & & & & $0.720 * * *$ & $(0.066)$ & 1.109 & $(0.124)$ \\
\hline Parent has bachelor's & & & & & $1.314 * * *$ & $(0.092)$ & $1.663 * * *$ & $(0.137)$ \\
\hline Grandparent has bachelor's & & & & & 1.047 & $(0.077)$ & $1.301 * *$ & $(0.111)$ \\
\hline \multicolumn{9}{|l|}{ High school type (vs. public) } \\
\hline Catholic school & & & & & $0.750 * * *$ & $(0.065)$ & 1.067 & $(0.099)$ \\
\hline Private school & & & & & $0.709 *$ & $(0.100)$ & 1.032 & $(0.133)$ \\
\hline Student held back & & & & & 1.077 & $(0.099)$ & 0.797 & $(0.117)$ \\
\hline Test score (std) & & & & & 1.062 & $(0.037)$ & 1.079 & $(0.050)$ \\
\hline Daycare & & & & & 1.112 & $(0.067)$ & 1.092 & $(0.082)$ \\
\hline Nursery school & & & & & $1.149 *$ & $(0.074)$ & $1.407 * * *$ & $(0.124)$ \\
\hline Head Start & & & & & 0.889 & $(0.075)$ & 1.127 & $(0.122)$ \\
\hline Kindergarten & & & & & $1.402 *$ & $(0.234)$ & 1.058 & $(0.221)$ \\
\hline Constant & $0.426 * * *$ & $(0.037)$ & $0.144 * * *$ & $(0.021)$ & $0.214 * * *$ & $(0.070)$ & $0.035 * * *$ & $(0.014)$ \\
\hline Observations & \multicolumn{4}{|c|}{14,872} & \multicolumn{4}{|c|}{14,872} \\
\hline Log-likelihood & \multicolumn{4}{|c|}{$-3,233,000$} & \multicolumn{4}{|c|}{$-2,906,282$} \\
\hline McFadden's Adjusted R ${ }^{2}$ & \multicolumn{4}{|c|}{0.049} & \multicolumn{4}{|c|}{0.145} \\
\hline Cg Goodness-of-fit, $g=10$ [p-value] & \multicolumn{4}{|c|}{$56.186[<0.001]$} & \multicolumn{4}{|c|}{$60.053[<0.001]$} \\
\hline
\end{tabular}

Note: Standard errors in parentheses. $* * * \mathrm{p}<0.001, * * \mathrm{p}<0.01, * \mathrm{p}<0.05$ 
Table 4.

$\underline{\text { Representation of predictors of significant logistic regression results }(\mathrm{p}<0.01) \text { for } 13 \text { parental financial planning actions }}$

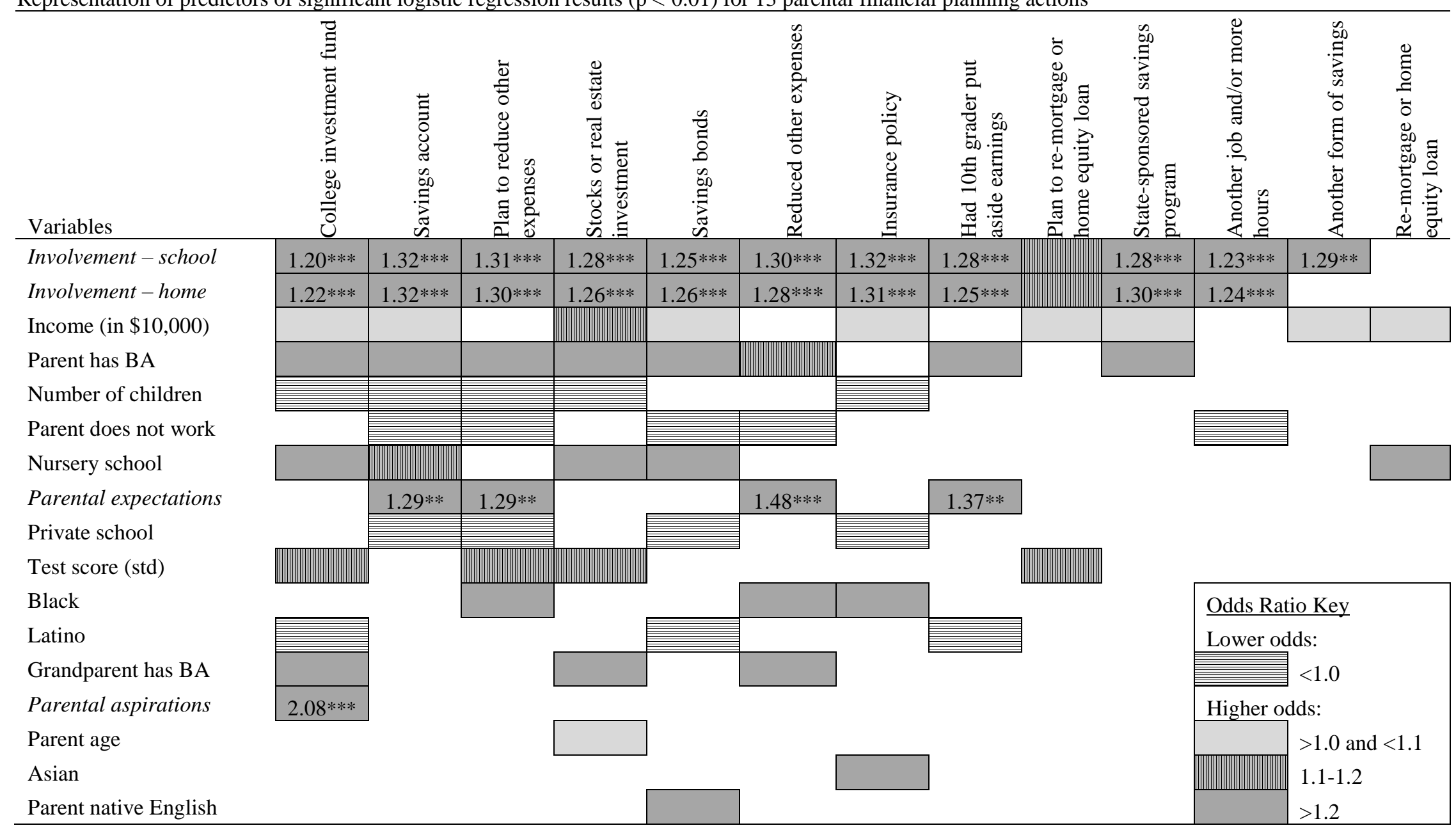

Note: Cultural capital variables in italics (effect sizes and significance added for the highest odds ratio group). Variables sorted by number of parental savings action models where they are significant. Actions sorted by number of significant variables in each model. $* * * p<0.001, * * p<0.01$ 